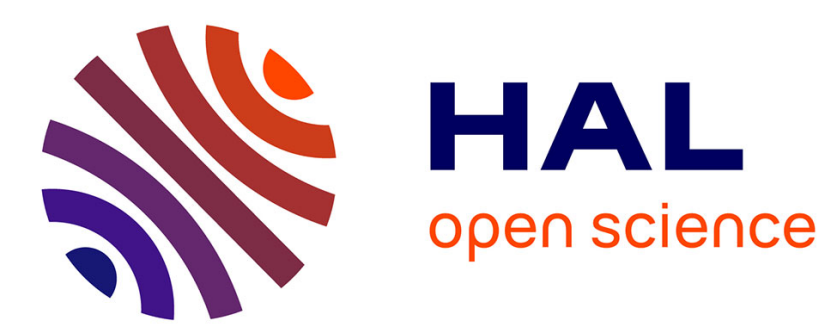

\title{
Grass inflorescence phytoliths of useful species and wild cereals from sub-Saharan Africa
}

Alice Novello, Doris Barboni

\section{To cite this version:}

Alice Novello, Doris Barboni. Grass inflorescence phytoliths of useful species and wild cereals from subSaharan Africa. Journal of Archaeological Science, 2015, 59, pp.10 - 22. 10.1016/j.jas.2015.03.031 . hal-01438748

\section{HAL Id: hal-01438748 \\ https://hal.science/hal-01438748}

Submitted on 15 Nov 2018

HAL is a multi-disciplinary open access archive for the deposit and dissemination of scientific research documents, whether they are published or not. The documents may come from teaching and research institutions in France or abroad, or from public or private research centers.
L'archive ouverte pluridisciplinaire $\mathbf{H A L}$, est destinée au dépôt et à la diffusion de documents scientifiques de niveau recherche, publiés ou non, émanant des établissements d'enseignement et de recherche français ou étrangers, des laboratoires publics ou privés. 


\title{
Grass inflorescence phytoliths of useful species and wild cereals from sub-Saharan Africa
}

\author{
Alice Novello $^{1 *}$ and Doris Barboni ${ }^{2}$ \\ 1 \\ iPHEP, Institut de Paléoprimatologie, Paléontologie Humaine : Evolution et Paléoenvironnements, CNRS \\ UMR 7262 - Université de Poitiers, 6 rue Michel Brunet, F- 86022 Poitiers cedex, France \\ 2 \\ CEREGE UM34, Aix-Marseille Université, CNRS, IRD, BP80, F-13545 Aix-en-Provence cedex 4, \\ France \\ *corresponding author: novelloalice@gmail.com
}

\begin{abstract}
Dendritic phytoliths that precipitate in grass inflorescences are often used in archaeology to trace the use of cereals (i.e. grasses harvested for their edible grain) and their domestication by early human societies. High amounts of these morphotypes are sometimes interpreted in terms of cereal accumulation in archaeological contexts. In sub-Saharan Africa, few cereals were domesticated during the midHolocene, but many wild grasses are still largely harvested by modern societies for food. The harvesting of wild cereals is also considered as one of the first stages toward early grass domestication. To evaluate how well dendritic phytoliths and/or other phytoliths produced in the grass inflorescences could help trace the use of wild cereal grains in sub-Saharan Africa, we analyzed the phytolith content of 67 African species (including 20 wild cereals), and 56 modern soils. We used test-value analysis and ANOVA to evaluate how well grass inflorescences could be distinguished from leaf/culm parts based on their phytolith content. We also measured the abundances of these phytoliths in natural soils from sub-Saharan Africa to provide a benchmark percentage abundance above which anthropogenic accumulation may be suspected in archaeological deposits. Our results confirm that, although rondel type phytoliths are abundant, only the dendritic phytolith morphotype is exclusive to the grass inflorescences. Yet, dendritic phytoliths do not occur in all species. They happen to be most frequent and found in greatest abundance ( $>34 \%$ relative to total phytolith count) in Panicoideae grasses (Sehima ischaemoides, Sorghastrum stipoides, and Sorghum purpureo-sericeum), and in one Eragrostideae species (Eragrostis squamata), which are not considered cereals. Inflorescences of the wild African cereals studied here do not happen to be particularly rich in dendritics $(<7 \%$ in average). Finally, dendritics are rare in modern natural soils $(<1 \%$ relative to total phytolith count, $<3 \%$ relative to sum of grass silica short cells plus dendritics), even under stands of rich dendritic producers. We conclude that dendritic phytoliths may be used for tracing remarkable deposits of grass inflorescences at archaeological sites in sub-Saharan Africa, but are not exclusive to domesticated or wild cereals. Abundances of dendritics $>>3 \%$ relative to sum of grass silica short cell phytoliths plus dendritics are likely to indicate anthropogenic accumulation of grass inflorescences. Yet, the absence or low abundance of dendritic phytoliths in archaeological deposits may not always indicate the absence of anthropogenic accumulation of grass inflorescence material.
\end{abstract}

Keywords: Poaceae; silica; dendritic; rondel; archaeology; paleoecology 


\section{Introduction}

Phytoliths are used to elucidate plant phylogeny (e.g. Prasad, et al., 2011, Strömberg, 2011), to study past vegetation dynamics and paleoenvironments (e.g. Coe, et al., 2014, Garnier, et al., 2013, Miller, et al., 2012), and as paleovegetation and paleoclimate proxies (e.g. Aleman, et al., 2012, Novello, et al., 2012, Strömberg, et al., 2007, Bremond et al., 2012, Fredlund and Tieszen, 1997). Phytoliths are also used in archaeology to infer early human living environments (e.g. Barboni, et al., 2010, Rossouw and Scott, 2011, WoldeGabriel, et al., 2009) and diet (e.g. Power et al., 2014, Henry, et al., 2014), as well as early agriculture (e.g. Pearsall, et al., 2003, Rosen and Weiner, 1994, Zhao and Piperno, 2000).

At archaeological sites, there is a particular interest in using grass phytoliths preserved in deposits to document past human activities integrating Poaceae species as primary resources (Albert, et al., 2008, Cabanes, et al., 2010, Harvey and Fuller, 2005, Iriarte, et al., 2010, Madella, et al., 2013, Mercader, 2009, Portillo, et al., 2010). For instance, grass phytoliths are largely searched for to study the first stages of cereal domestication ( $\mathrm{Lu}$, et al., 2009, Pearsall, et al., 2003, Ranere, et al., 2009, Zhao and Piperno, 2000), early associated farming practices (e.g. irrigation) (Rosen and Weiner, 1994), and different processing (e.g. harvesting, threshing, storage, and pounding) that precede grass consumption (Harvey and Fuller, 2005). The multi-potentiality of grass phytoliths is linked to the fact that silica deposition occurs in roots, culms, leaves, and inflorescences and in different types of cells (e.g. Parry and Smithson, 1964, Piperno, 2006), offering a large range of morphotypes to explore for paleoenvironmental and archaeological perspectives.

Particularly interesting for archaeology, Rosen (1992) observed that culm (straw) and husks (inflorescences bracts) of grasses produce different cell patterns that allow determining plant parts. Grass culm epidermis has basically the same cell pattern as leaves; they are characterized by "long-cells, short-cells and stomata aligned in longitudinal strips...long-cells are narrow (ca 5-10 microns in width), with side walls that are smooth or slightly sinuous... Papillae are absent". Grass husks (inflorescence bracts comprising glumes, lemmas and paleas) "include comparatively wide long-cells (ca 15-20 microns)... pronounced sinuosity of the longcell walls" (leading to the characteristic elongate dendritic types), “...often very thick long-cell walls and numerous papillae with elaborate ornamentations". Yet, her observations do not mention bulliform cells and hairs in culms, and prickles, hairs, stomata, and short cells that abundantly produce "hats" (i.e. rondel type phytoliths, ICPN, Madella, et al., 2005) in husks (Parry and Smithson, 1966). To our knowledge, the phytolith type redundancy between grass culms/leaves, on the one hand, and grass inflorescences, in the other hand, has been explored (e.g. Albert et al., 2008, Mulholland, 1989, Parry and Smithson, 1966, Rosen 1992), but never statistically demonstrated.

Bio-archeologists have largely investigated the inflorescence phytolith signal of the Pooideae as this subfamily of grasses includes several cereals: rye (Secale), barleys (Hordeum), wheat (Triticum) and oats (Avena) species which early domestication is associated with the Fertile Crescent in the Near East 12,000 to 9,000 years BP (Harlan, 1971, Larson, et al., 2014). To provide taxonomical identification of these cereal species, Ball and colleagues developed a morphometric approach applied to the dendritic phytoliths and to the silicified tissues of the grass inflorescences (Ball, et al., 1999, Ball, et al., 2009, Portillo, et al., 2006). A morphometric approach was also successfully applied to the double-peaked glume phytoliths produced by Oryza species to distinguish domesticated rice (Oryza sativa) from wild Oryza species in Asia (e.g. Zhao et al., 1998). Conversely, few phytolith studies have dealt with early grass domestication in Africa (Fahmy, 2008, Fahmy and Magnavita, 2006, Radomski and Neumann, 2011).

Plant domestication in Africa occurred during the middle Holocene between 8,200 and 4,200 years BP in three key regions: the West African savannas in the Sahel, the Sudanic savannas, and the Ethiopian plateau (e.g. Fuller and Hildebrand, 2013). Cereals that were domesticated are pearl millet (Pennisetum glaucum), fonio (Digitaria exilis), black fonio (Brachiaria deflexa), and African rice (Oryza glaberrima) in the Sahel, sorghum (Sorghum bicolor) in the Sudanic savannas, and tef (Eragrostis tef), finger millet (Eleusine coracana) and Ethiopian oat (Avena abyssinica) in the Ethiopian plateau (see review in Larson et al., 2014). Domestication was a long and complex process, which involved ecological, biological, and human cultural factors, and which lead to morphological and phenological changes collectively referred to as the domestication syndrome (Purugganan and Fuller, 2009). The domestication syndrome "is defined by a wide 
variety of traits that, depending on the species, may include: a reduced ability to disperse seeds without human intervention, reduction in physical and chemical defenses, reduction in unproductive side-shoots, reduction in seed dormancy, bigger seeds, more predictable and synchronous germination, and in some seedpropagated species, bigger and more inflorescences. (...) Recent genetic and archaeological research, however, has demonstrated that not all of these traits arose at the same time in either plants or animals" (Larson, et al., 2014). Because phytoliths in grass inflorescences can contribute to reinforce the toughness of the glume, their greater abundance in the Pooideae cereals may be a response to increased seed mass during domestication. To our knowledge, however, the relationship between seed mass and silicon content of inflorescences of domesticated versus wild cereals has never been tested.

Botanical studies of crops and their sister taxa are necessary to assess what differences have evolved between domesticated and wild plants (Fuller and Hildebrand, 2013). To date, few phytolith studies applied to research on cereal domestication and agriculture in Africa have done so. Radomsky and Neumann (2011) showed that some cereal genera, e.g. Oryza, Digitaria, and Sorghum, produce remarkable phytolith assemblages in their inflorescences, but the difference between wild and domesticated subspecies of African rice, pearl millet and sorghum cannot be determined so far. They suggest that these taxa can still be identified in the archaeological record based on their phytolith assemblages. However, given the phytolith type redundancy in grasses from the same group e.g. the Panicoideae, these cereal species could easily be mistaken with other grass species producing the same phytolith assemblages. More studies, notably on wild cereals are therefore needed.

In the Sahel, wild grass cereals were harvested by nomadic tribes before domestication (de Wet, 2009). Even today wild grass cereals represent a valuable supplemental food source in many areas where agriculture is poorly developed and/or when products from crops are insufficient (Harlan, 2009). Numerous wild grass cereals, e.g. Brachiaria deflexa (Guinea millet), Panicum laetum (wild fonio), and Oryza longistamina (wild rice), are still harvested from natural stands by local populations for food in the Sahel. Other useful grasses, e.g. Andropogon gayanus are harvested for forage, fiber or medicinal uses, etc. (Table 1) (PROTA4U).
Plant species other than those belonging to the grass (Poaceae) family (e.g. quinoa) are often considered as cereals based on the fact that their seed is harvested for human consumption (FAO, 2015). In this paper, however, we follow the sensu stricto definition of "cereals" i.e. species exclusively of the Poaceae (grass) family, whose caryopsis (grain, seed) is harvested and used for food by humans. Wild grass cereals are harvested from natural stands. Their caryopses are not (or cannot be) planted as seed corn for next year's crop, on the contrary to cultivated and domesticated grass cereals (Davies and Hillman, 1992; Harlan, 1992).

In order to contribute to making phytoliths a valuable tool to further explore early use of cereals in sub-Saharan Africa, we provide here a thorough analysis of the phytolith content of 67 African grass species, which include 20 wild cereals and 47 other useful species in the Sahel. First we evaluate the potential for phytoliths to characterize grass inflorescences, and then we evaluate how abundant these inflorescence phytoliths need be in archaeological deposits to confidently infer anthropogenic accumulation of grass inflorescences.

\section{Material and Methods}

\subsection{Modern grass and surface soil samples}

We analyzed 67 non-domesticated grass species, which occurrence in Sahelian and Sudanian savannas is largely documented (César and Lebrun, 2003, Poilecot, 1999). Among these species, 57 were sampled from the ALF herbarium (CIRAD, Montpellier, France), and 10 were sampled during a fieldwork campaign carried out in Chad in October 2010. Our dataset includes five species from the Aristidoideae subfamily (Aristideae tribe), 17 species from the Chloridoideae subfamily (Cynodonteae, Eragrostideae, and Pappophoreae tribes), two species from the Ehrhartoideae subfamily (Oryzeae tribe), and 43 species from the Panicoideae subfamily (Andropogoneae, Paniceae, Arundinelleae tribes) (Clayton, et al., 2006, Watson and Dallwitz, 1992) (Table 1). When available, common names of the grass species, as well as information concerning their current uses by African populations are given in Table 1 (PROTA4U).

We also considered a set of 56 modern (surface) samples from Chad (including 25 
samples already published, Novello, et al., 2012), in order to test how well grass inflorescence phytoliths could be found preserved in sediments. These samples were collected in non-cultivated areas, in natural soils under different vegetation types within the Sudanian and Sahelian phytogeographical zones (White, 1983). Nine samples were collected on current Lake Chad margins (Table A1).

\subsection{Laboratory procedures}

For each species, leaf/culm parts (hereafter often indicated just as "leaf") and inflorescences were sampled separately and from one single grass specimen. We used up to $5 \mathrm{~g}$ of thoroughly washed leaf or inflorescences for the grass species sampled in the field, but $<1 \mathrm{~g}$ for those sampled in the herbarium in order to preserve the botanical specimen. Organic matter was digested by successive nitric $\left(\mathrm{HNO}_{3}, 65 \%\right)$ and perchloric $\left(\mathrm{HClO}_{4}, 70 \%\right)$ acid treatments at $80-90{ }^{\circ} \mathrm{C}$, and completed by digestion with hydrogen peroxide $\left(\mathrm{H}_{2} \mathrm{O}_{2}, 33 \%\right)$, at $90^{\circ} \mathrm{C}$. Soil sediment samples also underwent acid digestion. Chemical treatment of approximately 10-15g of material included carbonate dissolution ( $\mathrm{HCl}, 37 \%$ overnight), organic matter oxidation $\left(\mathrm{H}_{2} \mathrm{O}_{2}\right.$ at $33 \%$, at $\left.90^{\circ} \mathrm{C}\right)$, iron removal (with $\mathrm{C}_{6} \mathrm{H}_{5} \mathrm{Na}_{3} \mathrm{O}_{7}$ and $\mathrm{Na}_{2} \mathrm{O}_{4} \mathrm{~S}_{2}, \mathrm{H}_{2} \mathrm{O}_{2}$ ), and clay removal by decantation. Densimetric separation with zinc bromide heavy liquid $\left(\mathrm{ZnBr}_{2}\right)$ set at $\mathrm{d}=2.3$ was used to concentrate the silica particles (including phytoliths, diatoms, and sponge spicules). We used glycerin as mounting medium to allow the observation of phytoliths in the three dimensions and counting. Extra slides mounted with Canada balsam were used for the photographs. Microscopic observations were done at $\mathrm{x} 400$ and $\mathrm{x} 1000$ magnification. Whenever possible, we counted a minimum of 200 and 400 phytoliths for each plant and soil sample, respectively (Table 1). Phytolith morphotype abundances were then expressed as percentage values calculated on the total sum of phytolith counted or else whenever indicated.

\subsection{Classification of the phytolith types}

During microscopic analysis we distinguished and counted separately all phytolith morphotypes. Phytoliths were described and classified according to their 3D morphology following Novello et al. (2012). Five categories of grass silica short cells (GSSCs) were recognized: rondel and cubic trapeziform bodies (Ro- and Tra-), bilobate (Bi-), cross (Cr-), polylobate (Poly-), and saddle (S-) bodies, as well as three main categories of silicified long cells: acicular (Aci-), blocky (Blo-), elongate (El-) bodies, and three other categories: globular (Glo-), polyhedral plate (Pla-), and epidermal silicified structures (including articulated epidermal structure from grasses Str-, stomata Sto-, and tracheids Trach-). Five GSSC types, not described in Novello et al. (2012) were added to the previous classification (Plate I). They include two polylobate types: Poly2 (tabular polylobate with five or more well-defined rounded lobes) and Poly3 (trapeziform polylobate, base irregularly sinuate with closed concavities/convexities and tabular to keeled top), and two saddle types: S6 (parallelepipedal short saddle with convex edges shorter than concave edges) and S7 (pseudo-long saddle in base view, deeply concave in side view). Elongate phytoliths were distinguished according to their ornamentation: psilate (El3p), wavy (El3w), spiny (El3e), and dendritic (El3d) (Plate I).

\subsection{Phytolith data analysis}

Over the 67 leaves and 67 inflorescences we analyzed, four leaf and 23 inflorescence samples were found sterile or sub-sterile $(<50$ phytoliths), or had $<100$ phytoliths to entrust reliable percentage calculation (Table 1). Patterns of leaf and inflorescence phytolith production were compared among sub-families (Fig.1), and among species (Fig.2 and Fig.A1). To ease comparisons, lobate phytoliths (i.e. bilobate, cross, and polylobate types) were grouped together in Fig.2. Species with $>100$ phytoliths in both leaves and inflorescences (43 species in total) were used to run test-value analysis (TV analysis) (Lebart, et al., 2000), to identify statistically characteristic cohorts of phytolith types for grass leaves/culms, on the one hand, and for grass inflorescences on the other hand (Fig.3a-b). The TV is a criterion used for characterizing a group of observations (here grass species) according to a continuous or categorical variable (here leaf/culm and inflorescence categories). The groups are defined by categories from a discrete variable (GSSCs and silicified long cells). The TV analysis compares the values of a descriptive statistic indicator computed on the whole sample, and then computed on a subsample related to the group. Test-value is calculated as follows, 


$$
\text { Test value }=\frac{\mu_{\mathrm{g}}-\mu}{\sqrt{\frac{\mathrm{n}-\mathrm{n}_{\mathrm{g}}}{\mathrm{n}-1}} \times \frac{\sigma^{2}}{\mathrm{n}_{\mathrm{g}}}}
$$

where $\mu \mathrm{g}$ is the mean of the group, $\mu$ the mean of the whole dataset, $n$ the size of the group, $n_{g}$ the size of the whole dataset, and $\sigma^{2}$ the variance (Lebart, et al., 2000). All test-values were obtained by iteration of the original formula using R 2.13.0.

A phytolith type was considered characteristic of leaves or of inflorescences if the association phytolith-group was supported by a significant and exclusively positive testvalue, and if the mean abundance of the phytolith type was $>2 \%$. This threshold at $2 \%$ was set in order to account for the counting procedure, which is not strictly reproducible according to the observer, and may bring a percent error of ca. $2 \%$. We then carried out one-way ANOVA (aov function, $\mathrm{R} 2.13 .0$ ) to evaluate if the differences of mean percentage values of morphotypes identified by the TV analysis are significant between leaves and inflorescences (Fig.3c). The $p$-values obtained for each comparison are reported in Table A2. To apply ANOVA, we first rank-transformed the percentage data (rank function, $\mathrm{R} 2.13 .0$ ) to meet normality (shapiro.test function, $\mathrm{R}$ 2.13.0). All graphics were done using $\mathrm{R}$ 2.13.0.

\section{Results}

\subsection{Phytolith type diversity}

We identified 60 different phytolith morphotypes in the grass material, among which 42 GSSCs, plus two acicular types, six blocky types, six elongate types, and four others, including the globular type Glo5, the stomata type Sto1, the tracheid type Trac1, and the polyhedral plate type Pla9 (Table 1). Phytolith diversity is somewhat higher in the grass leaves than in the grass inflorescences. Indeed, three to 23 different phytolith types (12 in average) were observed in the leaves, against one to 17 different phytolith types (eight in average) in the inflorescences. Only three types were restricted to a given species: the elongate type El4 (cylindric, laminate, with a median swelling) occurred only in the leaves of Loudetia annua $(<1 \%)$, the blocky type
Blo2 (irregular with ill-defined shape, Plate I) occurred only in the leaves of Aristida funiculata (5\%), and the GSSC type S7 (pseudo-long saddle base with irregular margins, and reniform top deeply collapsed in side view, Plate I) was only observed in the inflorescences of Tragus berteronianus (16\% of the total phytolith sum) (Plate I).

\subsection{Poaceae taxonomy and the general pattern of phytolith production in the leaves/culms}

In agreement with the general pattern of phytolith production we found that most Panicoideae and Ehrhartoideae species (39/41 species) mainly produce lobate phytoliths (58$100 \%$ ) in their leaves, and that most Aristidoideae species (4/5) mainly produce bilobates (94-100\%) in their leaves (Fig.1). Exceptions, however, do exist. Among the Panicoideae, rondels account for up to $55 \%$ in the leaves of Andropogon gayanus var. tridentatus (Andropogoneae tribe), and saddles for up to $58 \%$ in the leaves of Sorghastrum stipoides (Andropogoneae tribe). One Aristidoideae species, Stipagrostis uniplumis, produces $92 \%$ of rondel phytoliths in its leaves (Fig.1). Regarding the Chloridoideae species, no common pattern of phytolith production can be identified. Saddles are found most abundant in the leaf tissues of $7 / 17$ species $(>77 \%)$, bilobates in the leaf tissues of 4/17 species (74$100 \%$ ), and rondels in the leaf tissues of $6 / 17$ species (85-99\%) (Fig.1). In details, bilobates were found in abundance in the leaf tissues of the genus Ctenium (two species), and of the species Enneapogon devauxii and Sporobolus helvolus, whereas rondels were found in abundance in the leaf tissues of the genus Eragrostis (four species) and Sporobolus (two species) (Fig.1).

There is no apparent relationship between grass tribes and the phytolith content of leaves/culms (or inflorescences). The phytolith production pattern of the tribes Aristideae, Eragrostideae, Cynodonteae, Andropogoneae, and Paniceae is heterogeneous: species within these tribes rarely have similar phytolith production patterns. For instance, within the Aristideae tribe, Aristida species mainly produce bilobates in their leaves, while Stipagrostis uniplumis produces mainly rondels (Fig.1). On the contrary, we found that species belonging to the same genus (usually) exhibit similar phytolith production patterns. This is the case for the species of the following genera (see Table 1 for species names): Aristida, Ctenium, Hyparrhenia, Pennisetum, Chloris, Eragrostis, and Loudetia (Fig.1). Exceptions, again, do exist, e.g. Andropogon gayanus var. 
tridentatus, which is one among the five Andropogon gayanus species we studied that has more rondel than bilobates in its leaves.

\subsection{Phytoliths in grass inflorescences}

Comparing grass silica short cell composition of leaves/culms versus inflorescences was eased by grouping the bilobate, polylobate, and cross types in the lobate category (Fig.2). Our results show that two main patterns may be observed. The most common pattern (a) is characterized by species for which leaves and inflorescences produce the same suite of phytolith types in relatively similar proportions, such as the most abundant morphological category (lobate, saddle, or rondel) in the leaves is also the most abundant in the inflorescences. Species such as e.g. Aristida funiculata and 15 others are characterized by lobate phytoliths (plus rondel in smaller amount) in both leaves and inflorescences. Other species such as Eragrostis barteri and seven others are characterized by dominant rondels in both leaves and inflorescences. The second pattern (b) is characterized, on the contrary, by species for which the suite of phytoliths in the leaves and inflorescences is different. In most cases, phytoliths are of the rondel category in the inflorescences (e.g. Aristida stipoides, Oryza longistamina, all five Andropogon species, and four other species). In Eragrostis squamata, however, phytoliths are of the rondel category in the leaves (plus saddles in small amounts) and of the lobate category in the inflorescences (plus rondels in small amounts) (Fig.2). The second pattern is observed in $13 / 43$ species (i.e. < one third of our dataset of sub-Saharan species with phytoliths found in both leaves and inflorescences).

The TV analysis has identified three types among the rondel, bilobate, and elongate categories, which are mainly produced by grass inflorescences, and seven types among the elongate, acicular, and bilobate categories, which are mainly produced by grass leaves. The three phytolith types mainly produced by the grass inflorescence parts consist of the tabular/parallelepipedal elongate type with dendritic margins El3d, the rondel type Ro1, and the bilobate type Bil1 (Fig.3b, Plate I). The seven phytolith types mainly produced by grass leaves/culms are the tabular/parallelepipedal elongate type with echinate margins El3e, the acicular type Aci1, and bilobate types $\mathrm{Bi} 1, \mathrm{Bi} 7, \mathrm{Bi} 8$, and $\mathrm{Bi} 14$ (Fig.3a, Plate I). Among the ten types identified from the TV analysis, however, only six types are produced in significantly different abundances between inflorescences and leaves: the El3d and Ro1 types, mainly produced by grass inflorescences, and the $\mathrm{Bi} 7, \mathrm{Bi} 8, \mathrm{Bi} 14$, and El3e types, mainly produced by grass leaves (Fig.3c). The tabular/parallelepipedal elongate with dendritic margins (El3d type, here after called dendritic) was found exclusive to grass inflorescences, while the tabular/parallelepipedal elongate with echinate margins (El3e type) is strictly observed in grass leaves (Fig.3c).

The two phytolith types El3d (dendritic) and Ro1 that are significantly produced by grass inflorescences differ in abundance among tribes or even genera. El3d type occurs in the inflorescences of 14/43 grass species but its relative abundance ranges from $<1 \%$ to $77 \%$ (Fig.4). Highest relative abundances of El3d type $(>17 \%)$ are associated with grass species of the Andropogoneae tribe (Panicoideae subfamily) and with the species Eragrostis squamata (Eragrostideae tribe, Chloridoideae subfamily). In particular, our specimens of Sorghastrum stipoides, Sorghum purpureo-sericeum, and Sehima ischaemoides had $77 \%, 52 \%$, and $34 \%$ of El3d type in their inflorescences, respectively (Fig.4). Our specimen of Eragrostis squamata had 39\% of El3d type in its inflorescences (Fig.4). Although rondels of Ro1 type are not exclusive to grass inflorescences, our statistical analyses indicate that they are produced in significantly higher abundances in grass inflorescences than in leaves (Fig.3). Type Ro1 occurs in the inflorescences of 24/43 grass species, in which it accounts for $<1 \%$ to $100 \%$ (Fig.4). High relative abundances of Ro1 type $(>28 \%)$ are associated with grass species of the tribes Andropogoneae and Aristideae, and the genus Eragrostis. Indeed, our four specimens of Andropogon gayanus (var. gayanus, bisquamulatus, polycladus, and tridentatus) produced $82-90 \%$ of Ro1 in their inflorescences, and our specimens of Eragrostis barteri and Eragrostis tremula produced $87 \%$ and $100 \%$ of Ro1 in their inflorescences, respectively. Finally, the type Ro1 account for $88 \%$ in the inflorescences of Aristida stipoides (Fig. 4).

\subsection{Grass inflorescence phytoliths in modern soils}

In 56 natural soils from Chad, we found that inflorescence phytoliths i.e. dendritics (El3d) and rondel with truncated top (Ro1) do occur (Fig.5). Dendritics (El3d) occur in few samples (8/56 modern soils) at low relative abundance $(<1 \%$ relative to total phytolith count, $<3 \%$ relative to sum of GSSCs plus 
dendritics). They are found most frequently in soil samples from the Sudanian domain but not always where big dendritic producers e.g. Eragrostis squamata and Hyparrhenia bagirmica are found most abundant in the vegetation. Rondel type Ro1, on the contrary, occurs in all soil samples with relative abundances ranging from $<1 \%$ to $21 \%$ (relative to the total phytolith sum). Differences between samples are emphasized when percentages are calculated on the sum of GSSCs only. In this case, relative abundances of Ro1 range from $2 \%$ to $53 \%$ (Fig.5). High percentages of Ro1 $(>21 \%)$ are observed in half of our surface soil samples from both the Sahelian and the Sudanian domains.

\section{Discussion}

We are aware that our grass dataset of 67 species is small compared to the diversity of Poaceae in sub-Saharan Africa, where $>300$ grass species have been inventoried thus far just for Chad (César and Lebrun, 2003). Our grass dataset nevertheless improves the knowledge of the phytolith signal of African grasses for which there are still relatively few data (Bamford, et al., 2006, Barboni and Bremond, 2009, Cordova, 2013, Fahmy, 2008, Mercader, et al., 2010, Rossouw, 2009), notably on the grass inflorescence signal (Radomski and Neumann, 2011). Our grass dataset voluntary does not include domesticated grass species per se because we aimed at documenting the phytolith signal of useful wild grass and wild cereal species of sub-Saharan Africa. Also, 66 out of the 67 grass species we studied here are frequently used by African populations in sub-Saharan (Table 1) (PROTA4U). We also studied several species belonging to genera that are currently cultivated in tropical Africa (Digitaria, Brachiaria, Eragrostis, Oryza, Sorghum, and Pennisetum) (César and Lebrun, 2003, Poilecot, 1999). Our grass dataset is therefore appropriate for studying grasses potentially involved with past African populations and the process of domestication. For phytolith research as a whole, our phytolith data could also be used as a referential to interpret grass phytolith assemblages for paleoenvironmental studies in the Tropics, where Arundinoideae, Panicoideae and Chloridoideae species are largely distributed (Twiss, 1992). At last, our dataset provides percentages obtained from the phytolith analysis of just one specimen per species, which does not allow accounting for the natural intra-specific variability. Hence, the study of other specimens may provide slightly different results.
Our results show that there are two main patterns of phytolith production that characterize sub-Saharan grass species. Both patterns of production are observed in all grass subfamilies, tribes, and genera, without distinction, and may also both occur within the same genus. The most common pattern (a) is that grass leaves and grass inflorescences of a given species produce a similar suite of phytolith types, with the most abundant type in the leaves being also the most abundant type produced in the inflorescences. Although rondel phytoliths will be occurring in greater abundance in inflorescences than in leaves, the phytolith signal between leaves and inflorescences remains consistent. The second pattern (b) is characterized by remarkable differences between leaves and inflorescences, such as the suite of phytoliths in the inflorescences is largely dominated by rondels (e.g. Andropogon spp.). We found that the second pattern (inflorescences different) is less common. Differences in the phytolith composition between grass leaves and inflorescences were also observed for North American grass species, with rondels occurring in greater abundance in the inflorescences (6$39 \%)$ than in the leaves $(\leq 5 \%)$, e.g. in Calamovilfa longifolia (Chloridoideae), Panicum virgatum, or Zea mays (Panicoideae) (Mulholland, 1989). Such differences, however, are minor and indicate that the 19 North American grass species studied by Mulholland (1989) exclusively follow the first pattern (a): leaves and inflorescences have similar suites of phytoliths. In terms of biomass, inflorescences produce less tissue than leaves. They are therefore unlikely to significantly bias the phytolith signal of (paleo)-vegetation carried in the soils and paleosols.

Statistics on the leaves/culms and inflorescences phytolith assemblages show that rondel, particularly those that are truncated at the top (Ro1) are characteristic for inflorescences and so are dendritics (Eld3). However, Ro1 are so frequently found in grass leaves that the inflorescence origin will be hard to assess when dealing with sediment or soil material, unless dendritics are also found in abundance with these rondel phytolith types. Indeed, on the contrary to Ro1, dendritic elongate phytoliths (Eld3, Plate I) are exclusively observed in grass inflorescences (Fig.3). The strict relationship between the dendritic elongate type and the grass inflorescences is in agreement with previous studies on grass material (Rosen, 1992). This result, therefore, supports the use of dendritic elongates as indicator of grass inflorescences in archaeological deposits (Albert, et al., 2008, Cabanes, et al., 2010, Madella, 2011). 
Dendritic elongate phytoliths, however, cannot be used to infer the use of domesticated cereals (Albert, et al., 2008), because they are also abundantly produced by some wild species (this study, Radomski and Neumann, 2011), some of which being wild cereals others not (Fig.4). Albert et al. (2008) found $7-8 \%$ of dendritic phytoliths in the domesticated European cereals Avena, Triticum and Hordeum (Pooideae subfamily). In our study of African species (Aristidoideae, Ehrhartoideae, Chloridoideae and Panicoideae subfamilies), we found $1-20 \%$ of dendritic phytoliths in the inflorescences of the wild cereals Oryza longistamina, Andropogon pseudapricus, Echinochloa obtusiflora, Echinochloa stagnina, and Panicum laetum, and $1-77 \%$ dendritic phytoliths in the inflorescences of some of the grass species commonly used for forage/feed of domesticated animals (Fig.4). Our data suggest that there may be no relationship between the abundance of dendritic phytoliths in grass inflorescences and the fact that cereals have supposedly bigger seeds. Additional data on seed mass and on phytoliths of several specimens to take into account intra-specific variability are needed to fully demonstrate this relationship.

Dendritic elongate phytoliths, also, do not occur in every grass species we investigated, but just in 14 out of the 44 species that had produced sufficient number of phytoliths (Fig.4). In archaeological deposits, the absence of dendritic phytoliths, therefore, may not always indicate the absence of anthropogenic accumulation of grass inflorescence material. Anthropogenic accumulation of inflorescence material from e.g. the wild cereal Oryza longistamina, which is a low producer of dendritic phytoliths, may therefore leave no traces detectable through phytolith analysis. Radomski \& Neumann (2011) observed that Sorghum bicolor arundinaceum and S. bicolor bicolor may be characterized by other phytolith types than the dendritic, e.g. by rondel and bilobate variant saddle-like. These grass silica short cells are equivalent to our morphotypes Bi12, S4, and S5, which we have not found in Sorghum purpureo-sericeum but in Cymbopogon shoenanthus var. proximus, Echinochloa obustiflora, and Hyparrhenia rufa (Fig.3). Rondel and bilobate variant saddle-like of Radomski and Neumann (2011), therefore, cannot be considered diagnostic of Sorghum. Other phytolith types may be diagnostic, e.g. the double-picked glume phytolith for Oryza (Radomski and Neumann, 2011, Zhao and Piperno, 2000) and glume papillae phytoliths for Digitaria (Radomski and Neumann, 2011). Our data cannot verify these previous finds because our inflorescence specimens of Oryza longistamina did not produce any double-picked phytoliths, and Digitaria ciliaris and D. gayana were unproductive (sterile samples). Yet, papillae phytoliths were observed in the inflorescences of Chloris lamproparia (9\% of the total phytolith sum).

In the soils, dendritic phytoliths account for less than $1 \%$ of the total sum of phytoliths, although species producing high abundances of this type are sometimes abundant at the sampling sites. At site 16, for example, Eragrostis squamata represents $>35 \%$ of the herbaceous cover (Fig.5), but dendritic phytoliths were not observed in the soil (Fig.5). Such discrepancy may be related to a bad preservation of the dendritic phytoliths in the soils. Differential preservation affects phytolith types, and environmental factors such as fire for instance may particularly be harsh on dendritic phytoliths (Cabanes, et al., 2011). The small relative abundance of dendritics in soils may also be explained by the fact that there are less phytoliths produced in the inflorescences than in the leaves and stems/culms of grasses. Hence, relatively less inflorescence phytoliths are deposited in soils and sediments (Mulholland, 1989). An amount of $<1 \%$ of dendritic elongates in modern natural soils of Africa ( $<3 \%$ on the total sum of dendritics plus GSSCs) implies that high abundances of this type in ancient soils or sediments could be anthropogenic. Madella (2011) observed 38-83\% of dendritics (on the total sum of dendritics plus GSSCs) in pit deposits surrounding the archaeological site of Kilise Tepe (Turkey). This percentage largely outnumbers what we found in natural modern soils of Chad. Such high abundances undoubtedly relate to (unnatural) accumulation by human activities since they are not observed in natural conditions. In some late Bronze and Iron Age deposits of Del Tor in Israel, however, dendritics represent less than $4 \%$ of the total phytolith assemblage (Albert, et al., 2008), which is close to what we observe in the natural uncultivated soils we studied here. Given that the count of dendritics obtained for these archaeological samples is far below 200 (the recommended minimum count to minimize the percent error), the error associated to a percentage of dendritics of $4 \%$ is likely to be greater than $\pm 6 \%$ (at $95 \%$ confidence) (Strömberg, 2009). We believe that it is hazardous to infer anthropogenic accumulation of grass inflorescence material in this case.

The anthropic accumulation of grass straws (i.e. culms and leaves) seems hardly traceable using our approach of quantifying phytolith morphotypes because barely any phytolith type identified by the ANOVA is exclusive to the leaves/culms (Fig.3). To seek 
evidences of anthropic accumulation of straws it may be more appropriate to quantify the amount of phytoliths (in $\mathrm{mg}$ or in number of phytoliths) per gram of dried sediment deposits (e.g. Shahack-Gross, et al., 2004).

\section{Conclusion}

Two phytolith types, the tabular/parallelepipedal elongate with dendritic margins, commonly called "dendritics", and the conical rondels with truncated top are preferentially produced by grass inflorescences, but only dendritics are diagnostic of this plant part which carries grass seeds. Dendritic phytoliths, therefore, may be used for tracing remarkable deposits of grass inflorescences at archaeological sites in subSaharan Africa. Dendritic phytoliths, however, are not exclusive to domesticated or wild grass cereals. In fact, we found that they are more abundant in non-cereal grasses used for animal fodder than in the wild cereal species, which modern populations may still harvest and eat today in the Sahel. Abundances of dendritics $>>3 \%$ relative to sum of grass silica short cell phytoliths plus dendritics are likely to indicate anthropogenic accumulation of grass inflorescences. Yet, given that dendritics are not produced by all grass species, the absence or low abundance of dendritic phytoliths in archaeological deposits may not always indicate the absence of anthropogenic accumulation of grass inflorescence material.

\section{Acknowledgments}

This work was partially carried out as part of AN's doctoral and post-doctoral research, which received the financial support of the CNRS and the Région Poitou-Charentes, and the Fondation des Treilles (Paris), respectively. We thank the Chadian Authorities (Ministère de l'Education Nationale de l'Enseignement Supérieur et de la Recherche, University of Ndjamena, CNAR), the Ministère Français de l'Enseignement Supérieur et de la Recherche (UFR SFA, University of Poitiers, CNRSINEE, ANR, Project ANR-09-BLAN-0238, PI's Michel Brunet), and the Ministère Français des Affaires Etrangères et Européennes (DCSUR Paris and French Embassy in Ndjamena, Chad; FSP, Project no. 2005-54 of the FrancoChadian cooperation) for financial support and permissions for conducting research in Chad. Grass specimens were collected in the field under the guidance of P. Poilecot and at the CIRAD herbarium under the guidance of $P$. Poilecot, O. Moretti, and B. Rosset. We thank
M. Pasturel (CEREGE, Aix en Provence) for helping with R scripts, and the two anonymous reviewers for their constructive comments on an earlier version of this manuscript.

\section{References}

Albert, R.M., et al., 2008. Phytolith-rich layers from the Late Bronze and Iron Ages at Tel Dor (Israel): mode of formation and archaeological significance, J Archaeol Sci 35, 57-75.

Aleman, J., et al., 2012. Reconstructing savanna tree cover from pollen, phytoliths and stable carbon isotopes, J. Veg. Sci. 23, 187-197.

Ball, T.B., et al., 1999. Identifying inflorescence phytoliths from selected species of wheat (Triticum monococcum, T. dicoccon, $T$. dicoccoides, and T. aestivum) and barley (Hordeum vulgare and $H$. spontaneum) (Gramineae) Am J Bot. 86, 1615-1623.

Ball, T.B., et al., 2009. Review of typologic and morphometric analysis of phytoliths produced by wheat and barley, Breeding Sci 59, 505-512.

Bamford, M.K., et al., 2006. Plio-Pleistocene macroplant fossil remains and phytoliths from Lowermost Bed II in the eastern palaeolake margin of Olduvai Gorge, Tanzania, Quatern Int 148, 95-112.

Barboni, D., Bremond, L., 2009. Phytoliths of East African grasses: An assessment of their environmental and taxonomic significance based on floristic data, Rev Palaeobot Palyno 158, 29-41.

Barboni, D., et al., 2010. Phytoliths infer locally dense and heterogeneous paleovegetation at FLK North and surrounding localities during upper Bed I time, Olduvai Gorge, Tanzania, Quaternary Res 74, 344-354.

Boudet, G., 1975. Manuel sur les pâturages tropicaux et les cultures fourragères, Ministère de la Coopération, p. 254.

Boughey, A.S., 1957. The physiognomic delimination of West African vegetation types, J W Afr Sci Ass 3, 148-165.

Bremond L., et al., 2012. Neotropical C3/C4 grass distributions - present, past and future. Global Change Biology 18, 2324-2334. 
Cabanes, D., et al., 2011. Stability of phytoliths in the archaeological record: a dissolution study of modern and fossil phytoliths, J Archaeol Sci 38, 24802490.

Cabanes, D., et al., 2010. Phytolith evidence for hearths and beds in the late Mousterian occupations of Esquilleu cave (Cantabria, Spain), J Archaeol Sci 37, 2947-2957.

César, J., Lebrun, J.-P., 2003. Flore du Tchad, Laboratoire de Recherches Vétérinaires et Zootechniques de Farcha, N'Djaména.

Clayton, W.D., et al., 2006. GrassBase - The Online world of grass flora. Available at: http://www.kew.org/data/grassesdb.html (accessed on October 2013).

Coe, H.H.G., et al., 2014. Understanding Holocene variations in the vegetation of Sao Joao River basin, southeastern coast of Brazil, using phytolith and carbon isotopic analyses, Palaeogeogr, Palaeocl 415, 59-68.

Cordova, C.E., 2013. $\mathrm{C}_{3}$ Poaceae and Restionaceae phytoliths as potential proxies for reconstructing winter rainfall in South Africa, Quatern Int 293, 121140.

Davies, M.S., Hillman, G.C., 1992. Domestication of cereals, in: Chapman, G.P. (Ed.), Grass Evolution and Domestication. Cambridge University Press, pp. 199-224.

de Wet, J.M.J., 1992. The three phases of cereal domestication, in: Chapman, G.P. (Ed.), Grass evolution and domestication, Cambridge University Press, pp. 176-198.

FAO, 2015. Definition and classification of commodities: cereals and cereal products.

http://www .fao.org/economic/the-

statistics-division-

ess/methodology/methodology-

systems/crops-statistics-concepts-

definitions-and-classifications

(accessed on March 2015]

Fahmy, A.G., 2008. Diversity of lobate phytoliths in grass leaves from the Sahel region, West tropical Africa: Tribe Paniceae, J Plant Syst Evol 270, $1-23$.

Fahmy, A.G., Magnavita, C., 2006. Phytoliths in a Silo: Micro-botanical Evidence from Zilum (Lake Chad Basin), NE Nigeria (C. 500 Cal BC), J Biol Sci 6, 824-832.
Fredlund G.G., Tieszen,L.T., 1997. Calibrating grass phytolith assemblages in climatic terms: Application to late Pleistocene assemblages from Kansas and Nebraska. Palaeogeography, Palaeoclimatology, Palaeoecology 136, 199-211.

Fuller, D.Q., Hildebrand, L., 2013. Domesticating plants in Africa, in: Mitchell, P., Lane, P. (Eds.), The Oxford handbook of African archaeology, Oxford University Press, Oxford, pp. 507-525.

Garnier, A., et al., 2013. Phytolith taphonomy in the middle- to late-Holocene fluvial sediments of Ounjougou (Mali, West Africa), Holocene 23, 416-431.

Harlan, J.R., 1971. Agricultural Origins: Centers and Noncenters, Science 174, 468-474.

Harlan, J.R., 1992. Origins and processes of domestication, in: Chapman, G.P. (Ed.), Grass evolution and domestication, Cambridge University Press, pp. 159175.

Harvey, E.L., Fuller, D.Q., 2005. Investigating crop processing using phytolith analysis: the example of rice and millets, Journal of Archaeological Science 32, 739-752.

Henry, A.G., et al., 2014. Plant foods and the dietary ecology of Neanderthals and early modern humans, J Hum Evol 69, 44-54.

Iriarte, J., et al., 2010. Late Holocene Neotropical agricultural landscapes: phytolith and stable carbon isotope analysis of raised fields from French Guianan coastal savannahs, J Archaeol Sci 37, 2984-2994.

Larson, G., et al., 2014. Current perspectives and the future of domestication studies, P Natl Acad Sci USA 111, 6139-6146.

Lebart, L., et al., 2000. Statistique Exploratoire Multidimensionnelle, in: Dunod (Ed.), pp. 181-184.

Lu, H., et al., 2009. Earliest domestication of common millet (Panicum miliaceum) in East Asia extended to 10000 years ago, P Natl Acad Sci USA 106, 7367-7372.

Madella, M., 2011. Understanding archaeological structures by means of phytolith analysis: a test from the Iron Age site Kilise Tepe-Turkey, in: Meunier, J.-D., Colin, F. (Eds.), Phytoliths - Applications in Earth 
Science and Human History., CRC Press, pp. 173-182.

Madella, M., et al., 2005. International Code for Phytolith Nomenclature 1.0, Ann Bot 96, 253-260.

Madella, M., et al., 2013. Millet microremains - an alternative approach to understand cultivation and use of critical crops in Prehistory, Archaeol Anthropol Sci, DOI: $10.1007 / \mathrm{s} 12520-013-0130-y$.

Mercader, J., 2009. Mozambican grass seed consumption during the Middle Stone Age, Science 326, 1680-1683.

Mercader, J., et al., 2010. Poaceae phytoliths from the Niassa Rift, Mozambique, J Archaeol Sci, 1953-1967.

Miller, L.A., et al., 2012. Eocene vegetation and ecosystem fluctuations inferred from a high-resolution phytolith record, Geol Soc Am Bull 124, 1577-1589

Mulholland, S.C., 1989. Phytolith shape frequencies in North Dakota grasses: a comparison to general patterns, J Archaeol Sci 16, 489-511.

Novello, A., et al., 2012. Phytolith signal of aquatic plants and soils in Chad, Central Africa, Rev Palaeobot Palyno 178, 4358.

Parry, D.W., Smithson, F., 1964. Types of Opaline Silica Depositions in the Leaves of British Grasses, Ann Bot 28, 169185.

Parry, D.W., Smithson, F., 1966. Opaline Silica in the Inflorescences of Some British Grasses and Cereals, Ann Bot 30, 525-538.

Pearsall, D.M., et al., 2003. Identifying maize in neotropical sediments and soils using cob phytoliths, J Archaeol Sci 30, 611627.

Piperno, D.R., 2006. Phytoliths. A Comprehensive Guide for Archaeologists and Paleoecologists, AltaMira Press (Rowman \& Littlefield), Oxford.

Poilecot, P., 1999. Les Poaceae du Niger, in: Agronomique, C.d.C.I.e.R., Genève, C.e.J.b.d., Nature, U.I.p.l.C.d.l. (Eds.), Boissiera (vol.56), Genève, p. 766.

Portillo, M., et al., 2006. Morphometric analysis of inflorescence phytoliths produced by Avena sativa L. and Avena strigosa Schreb., Econ Bot 60, 121-129.

Portillo, M., et al., 2010. Domestic activities and spatial distribution in Ain Abū
Nukhayla (Wadi Rum, Southern Jordan): The use of phytoliths and spherulites studies, Quatern Int 193, 174-183.

Power, R.C., Rosen, A.M., Nadel, D., 2014. The economic and ritual utilization of plants at the Raqefet Cave Natufian site: The evidence from phytoliths. J. Anthropol. Archaeol. 33, 49-65.

Prasad, V., et al., 2011. Late Cretaceous origin of the rice tribe provides evidence for early diversification in Poaceae, Nat Commun 2, 480.

PROTA4U, Plant ressources of Tropical Africa, Wageningen University. Available at: http://www.prota4u.info/ (accessed on April 2014).

Purugganan, M.D., Fuller, D.Q., 2009. The nature of selection during plant domestication, Nature 457, 843-848.

Radomski, K.U., Neumann, K., 2011. Grasses and grinding stones: inflorescence phytoliths from modern West African Poaceae and archaeological stone artefacts, in: Magnavita, S. (Ed.), Proceedings of the 6th International Workshop on African Archaeobotany, Africa Magna Verlag, Cairo, Egypt.

Ranere, A.J., et al., 2009. The cultural and chronological context of early Holocene maize and squash domestication in the Central Balsas River Valley, Mexico, P Natl Acad Sci USA 106, 5014-5018.

Rosen, A.M., 1992. Preliminary Identification of Silica Skeletons from Near Eastern Archaeological Sites: An Anatomical Approach, in: Rapp, G., Mulholland, S.C. (Eds.), Phytolith Systematics, Plenum, New York, pp. 129-147.

Rosen, A.M., Weiner, S., 1994. Identifying Ancient Irrigation: a New Method Using Opaline Phytoliths from Emmer Wheat, J Archaeol Sci 21, 121-132.

Rossouw, L., 2009. The application of fossil grass-phytolith analysis in the reconstruction of late Cenozoic environments in the South African interior, $\mathrm{PhD}$ Thesis, University of the Free State, Bloemfontein.

Rossouw, L., Scott, L., 2011. Phytoliths and Pollen, the Microscopic Plant Remains in Pliocene Volcanic Sediments Around Laetoli, Tanzania, in: Harrison, T. (Ed.), Paleontology and Geology of Laetoli: 
Human Evolution in Context, Springer, New York, pp. 201 - 215.

Shahack-Gross, R., et al., 2004. Reconstruction of spatial organization in abandoned Maasai settlements: implications for site structure in the Pastoral Neolithic of East Africa, J Archaeol Sci 31, 1395-1411.

Strömberg, C.A.E., 2009. Methodological concerns for analysis of phytolith assemblages: Does count size matter?, Quaternary Int 193, 124-140.

Strömberg, C.A.E., 2011. Evolution of grasses and grassland ecosystems, Annu Rev Earth Pl Sc 39, 517-544.

Strömberg, C.A.E., et al., 2007. The spread of grass-dominated habitats in Turkey and surrounding areas during the Cenozoic: Phytolith evidence, Palaeogeogr, Palaeocl 250, 18-49.

Twiss, P.C., 1992. Predicted world distribution of $\mathrm{C}_{3}$ and $\mathrm{C}_{4}$ grass phytoliths, in: Mulholland, S.C. (Ed.), Phytoliths Systematics Emerging Issues. Advance Archaeological Museum Science, pp. 113-128.

Watson, L., Dallwitz, M.J., 1992. GrassBase The Grass Genera of the World: descriptions, Illustrations, Identification, and Information Retrieval; Including Synonyms, Morphology, Anatomy, Physiology, Phytochemistry, Cytology, Classification, Pathogens, World and Local Distribution, and References. Available at: http://deltaintkey.com/grass/ (accessed on January 2012).

White, F., 1983. The Vegetation Map of Africa, Recherches sur les ressources naturelles, Office de la Recherche Scientifique et Technique Outre-Mer, United Nations Educational, Scientific and Cultural Organization, Paris, p. 384.

WoldeGabriel, G., et al., 2009. The geological, isotopic, botanical, invertebrate, and lower vertebrate surroundings of Ardipithecus ramidus, Science 326, 65e61-65.

Zhao, Z.J., Piperno, D.R., 2000. Late Pleistocene-Holocene environment in the middle Yangtze River valley, China, and rice (O. sativa) domestication, the phytolith evidence, Geoarchaeology 15, 203-222.

\section{Captions for Tables and Figures}

\section{Tables}

Table 1. List of the sub-Saharan grass species included in this study ( $\mathrm{N}=67$ species), common names, and current uses by modern African populations. Specimens were sampled in Chad (coordinates) or in the ALF herbarium (Montpellier, France) (herbarium number and country of sampling are given). Tribe affiliation follows Clayton et al (2006). Sterile to substerile samples $\left(\mathrm{N}_{\text {moys }}<42\right.$ particles) were not considered for statistical analyses. $\mathrm{N}_{\mathrm{spoc}}$ measures phytolith type diversity.

\section{Figures}

Figure 1. Relative abundances of the main phytolith categories in leaves and in inflorescences of 67 grass species from subSahara. Relative abundances are expressed according to grass subfamilies.

Figure 2. Relative abundances of main morphological categories of grass silica short cells (lobate, saddle, and rondel) in leaves/culms and in inflorescences of 43 subSaharan grass species, for which phytoliths were found in both leaves/culms and inflorescences.

Figure 3. T-values and mean abundances of the 60 phytolith morphotypes observed (a) in leaves/culms, and (b) in inflorescences of 43 sub-Saharan grass species. (c) Comparison between the mean abundances of the 10 phytolith types pointed out by the TV analysis in the leaves/culms and in the inflorescences. Phytolith types for which significant differences are observed between leaves/culms and inflorescences are framed in dotted line. All mean abundance values are given along with $95 \%$ confidence interval (CI).

Figure 4. Relative abundance of tabular/ parallelepipedal elongate phytoliths with dendritic margins (El3d, dendritics) and rondel type Ro1 phytoliths in the inflorescence tissues of 44 grass species from sub-Saharan Africa. Grass species are organized by sub-families. Species related to domesticated cereal genera are underlined. Bars are color-coded according to tribe affiliations. * indicates wild cereals.

Figure 5. Relative abundance of tabular/ parallelepipedal elongate phytoliths with dendritic margins (El3d, dendritics) and rondel type Ro1 in 56 natural surface soil samples from Chad. Ro1 percentages are given on the 
total sum of phytoliths, and also on the sum of grass silica short cells (GSSCs) only. E13d percentages are given on the sum of GSSCs plus El3d (dendritic phytoliths). Samples are organized by latitude, from north (top) to south (bottom), along with affiliations to major phytogeographical domains (according to White 1983). The relative abundance of the six grass species, which we found are the biggest producers of dendritic phytoliths $(>17 \%$ of dendritics in inflorescences), is given at the sampling sites. The scale used for grass species abundance at the sampling sites refers to Boudet (1975). Es: Eragrostis squamata; Ap: Andropogon pseudapricus; Cg: Cymbopogon giganteus; Hb: Hyparrhenia bagirmica; Si: Sehima ischaemoides; Sp: Sorghum purpureosericeum.

\section{Plates}

Plate I. Photographs of conspicuous phytolith types identified in grass inflorescences and leaves. A: New GSSC types, not previously described in Novello et al. 2012, plus the types (S7, Blo2, and El4) found diagnostic in this study. B, C: Phytolith types identified by the Test-Value analysis as preferentially produced by the leaves (B), and by the inflorescences (C). After the ANOVA analysis (Fig.3), only the types marked with $*$ are considered as significantly relevant to leaves/culms or inflorescences. Photographs were taken from the following specimens: Poly2: Echinochloa pyramidalis, leaf; Poly3: Brachiaria xantholeuca, inflorescence; S6: Sorghastrum stipoides, leaf; S7: Tragus berteronianus, inflorescence; Blo2: Aristida funiculata, leaf; El4: Loudetia annua, leaf; Bi1: Aristida stipoides, leaf; Bi2: Brachiaria deflexa, leaf; Bi7: Cymbopogon shoenanthus var. proximus, leaf; Bi8: Cymbopogon giganteus, leaf; Bi14: Panicum turgidum, leaf; Aci1: Aristida funiculata, leaf; El3e (a): Aristida funiculata, leaf; El3e (b): Echinochloa pyramidalis, leaf; Ro1: Aristida sieberiana, inflorescence; Bi11: Andropogon pseudapricus, inflorescence; El3d "dendritics": Sorghastrum stipoides, inflorescence. Scale bar applies to all photographs.

\section{Supplementary material}

Figure A1. Abundance diagrams of the main GSSC categories produced by grass species in their leaves and inflorescences (only the species producing phytoliths at least in one plant part were indicated, $=64$ species $)$.
Table A1. List of the non-cultivated modern soil samples analyzed for phytoliths. The grass species present at each site are indicated in the last column along with abundance scale data (2: $\leq 5 \%, 3: 5-35 \%, 4: 35-65 \%, 5: 65-100 \%$, Boudet, 1975). Only the species in bold were analyzed for phytoliths. Phytogeographical zones are from White (1983): SAHE EDAP: Sahelian edaphic grasslands, SAHE SWP/AQUA VEGT: Herbaceous swamp and aquatic vegetation, SAHE GRASS/BUSH: Sahel Acacia wooded grasslands and deciduous bushlands, SUDA WOOD: Sudanian undifferentiated woodlands, SUDA EDAPH: Sudanian edaphic grasslands, and vegetation physiognomy from Boughey (1957).

Table A2. $p$-values resulting from pairwise comparisons (one-way ANOVA) between leaf/culm and inflorescence percentages. Significant $p$-values $(<0.05)$ are indicated in bold. 


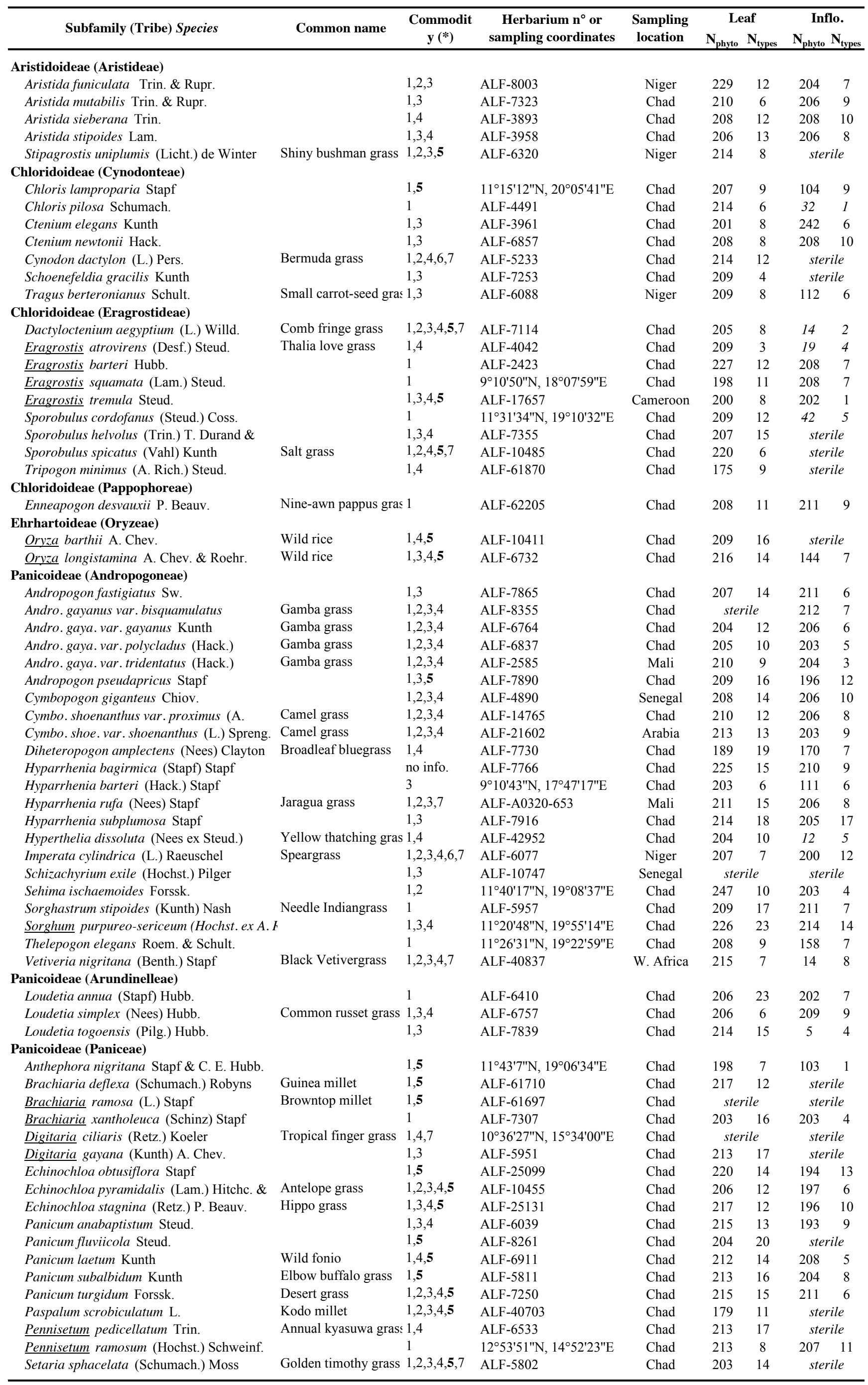

(*) Notes: 1: Forage/feed use, 2: Auxiliary use, 3: Fibre use, 4: Medicinal use, 5: Cereals, 6: Carbohydrate/starch use, 7: Ornemental use 

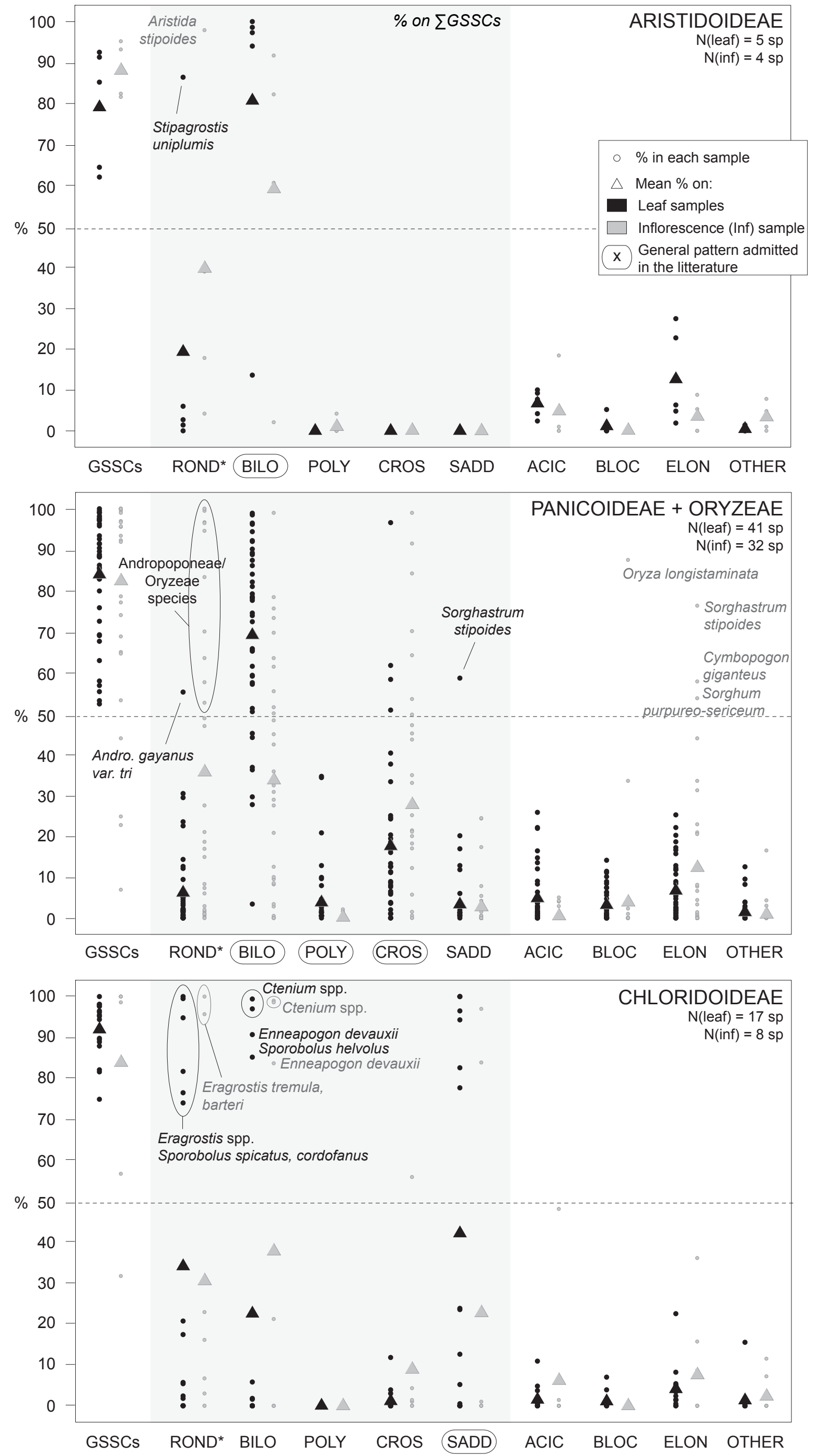

Fig. 1 

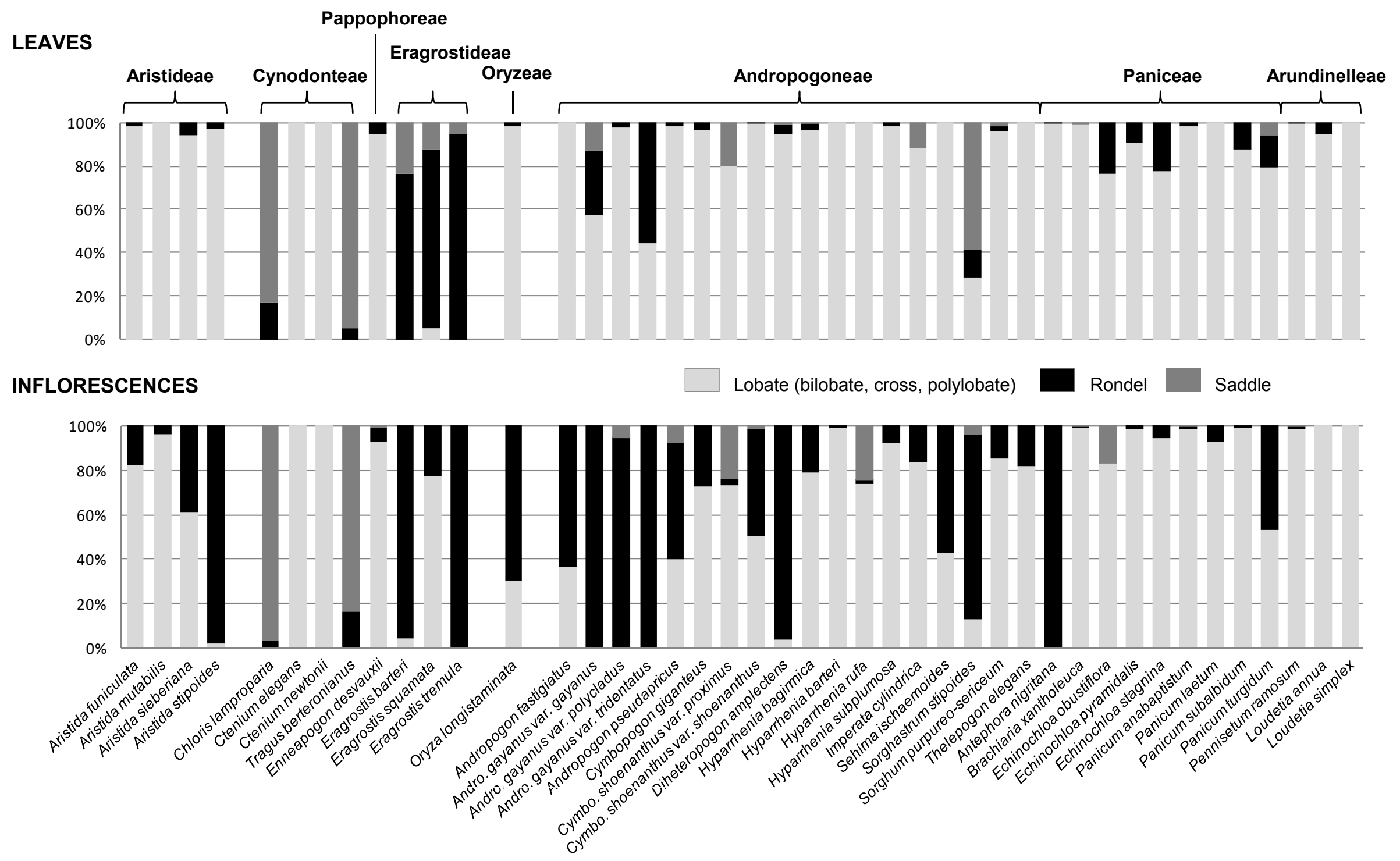

Fig.2

Novello \& Barboni 

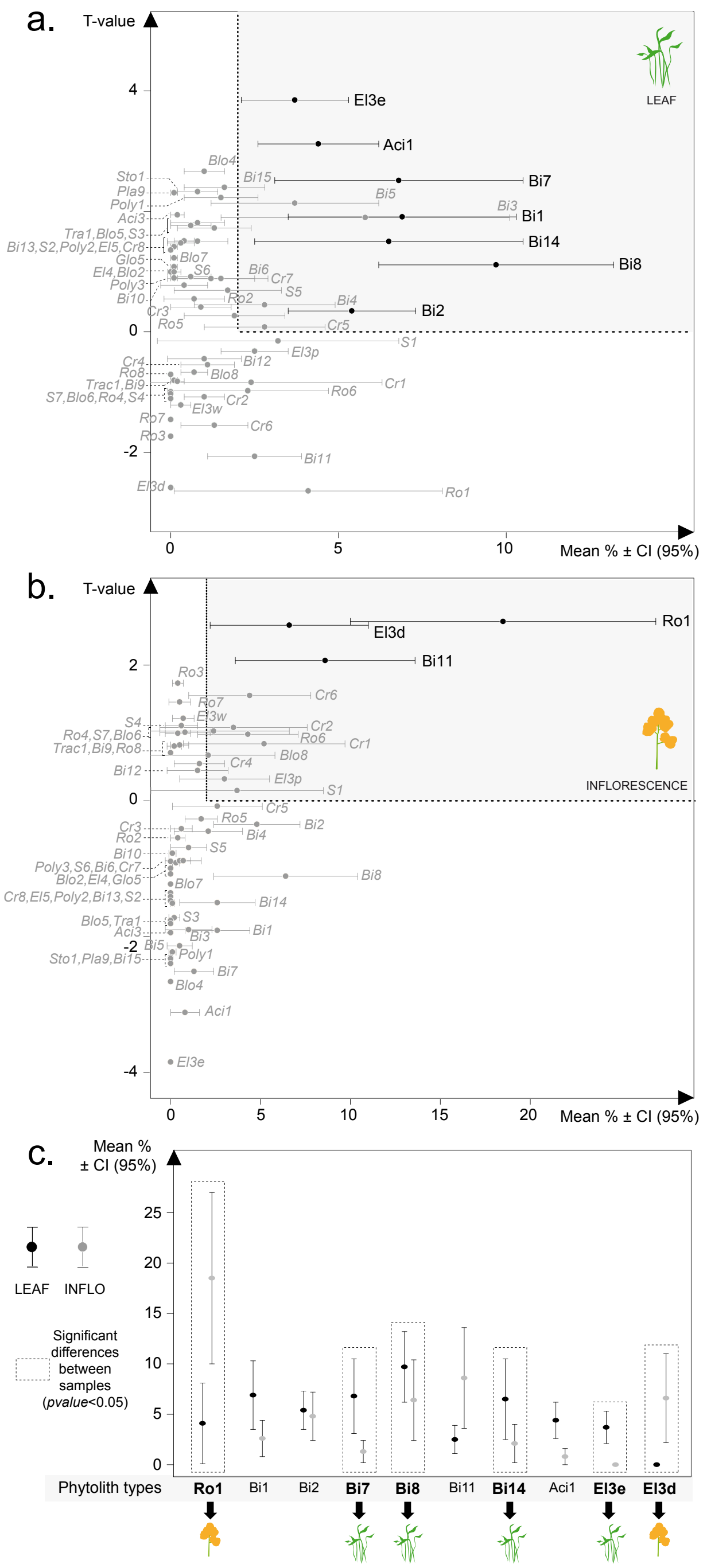

Fig.3

Novello \& Barboni 
\% Ro1 rondel type

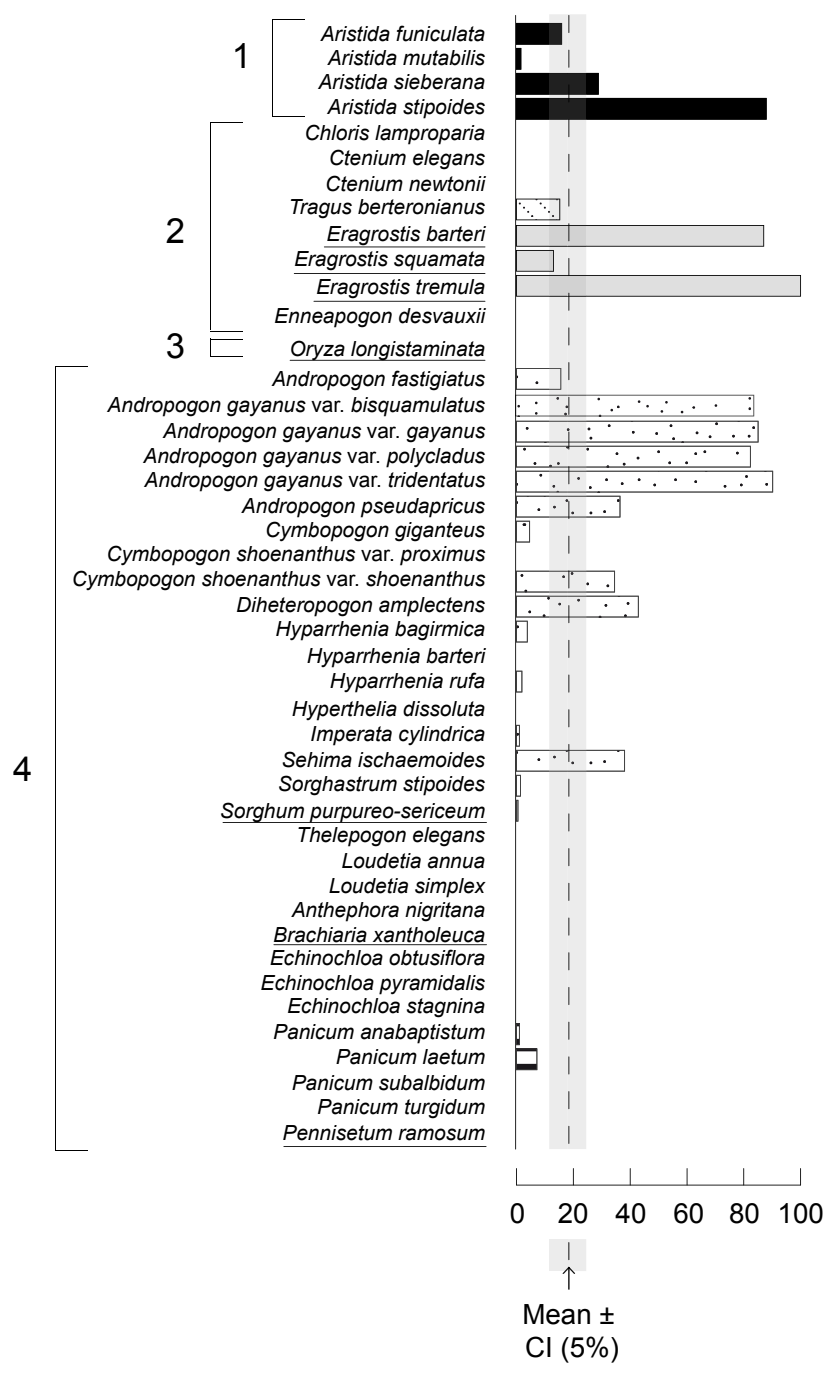

\% El3d elongate type

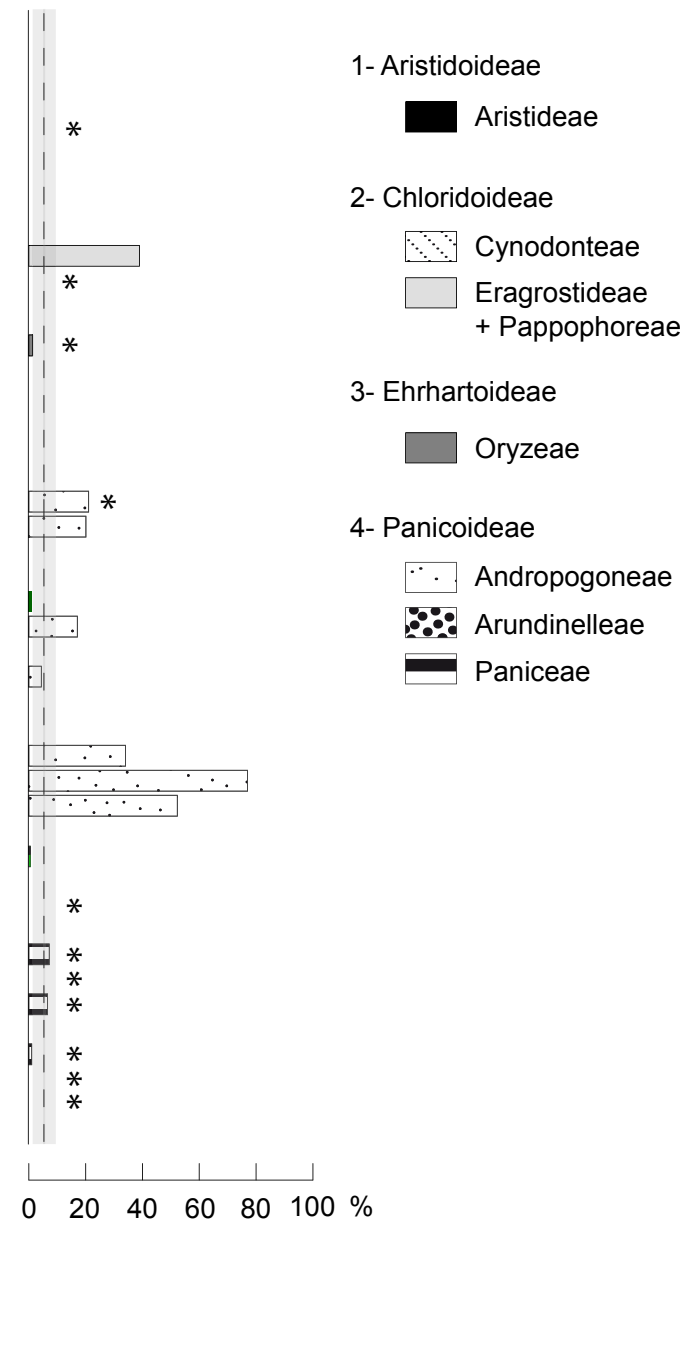

Fig. 4

Novello \& Barboni 

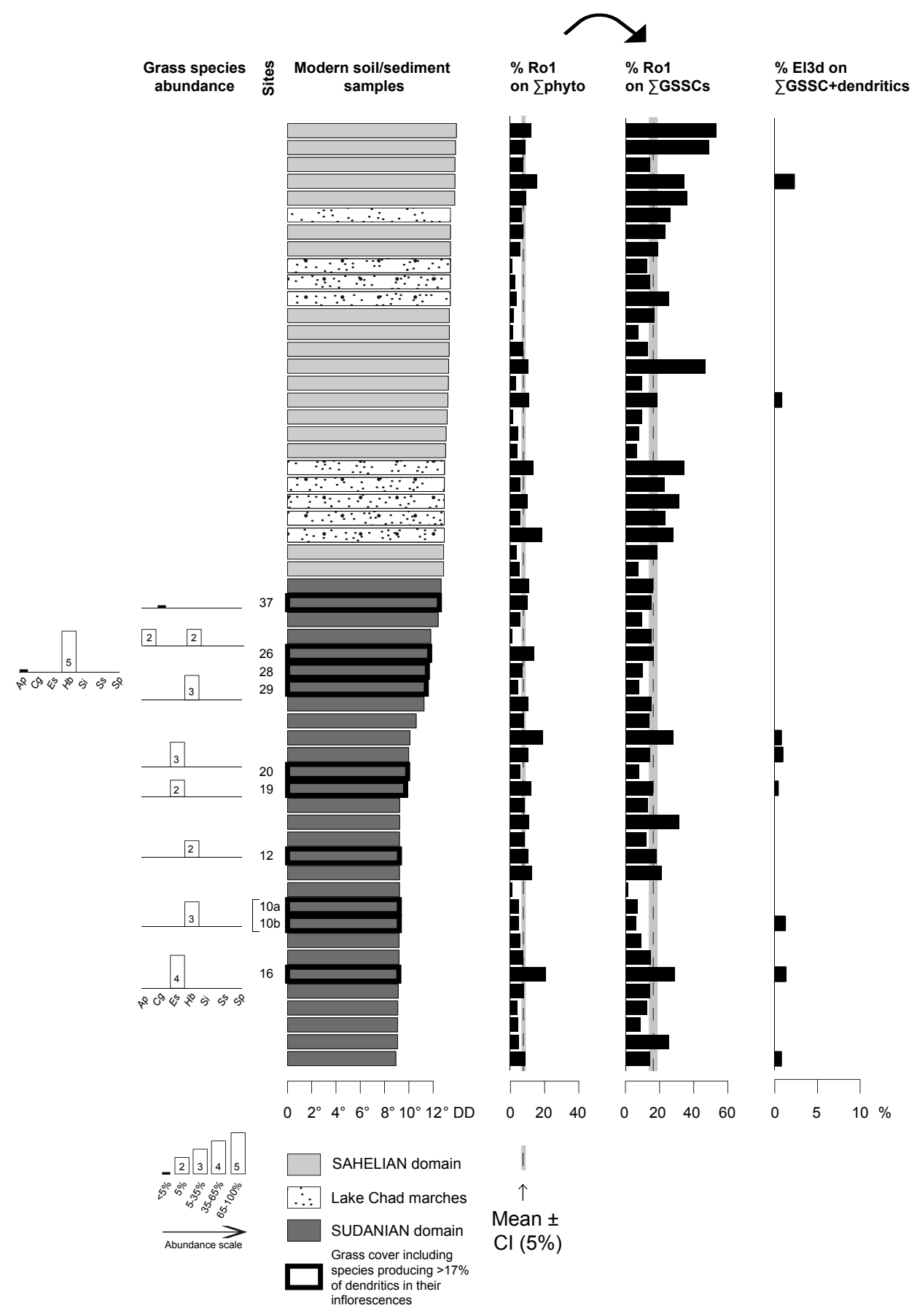

Fig.5

Novello \& Barboni 
A-

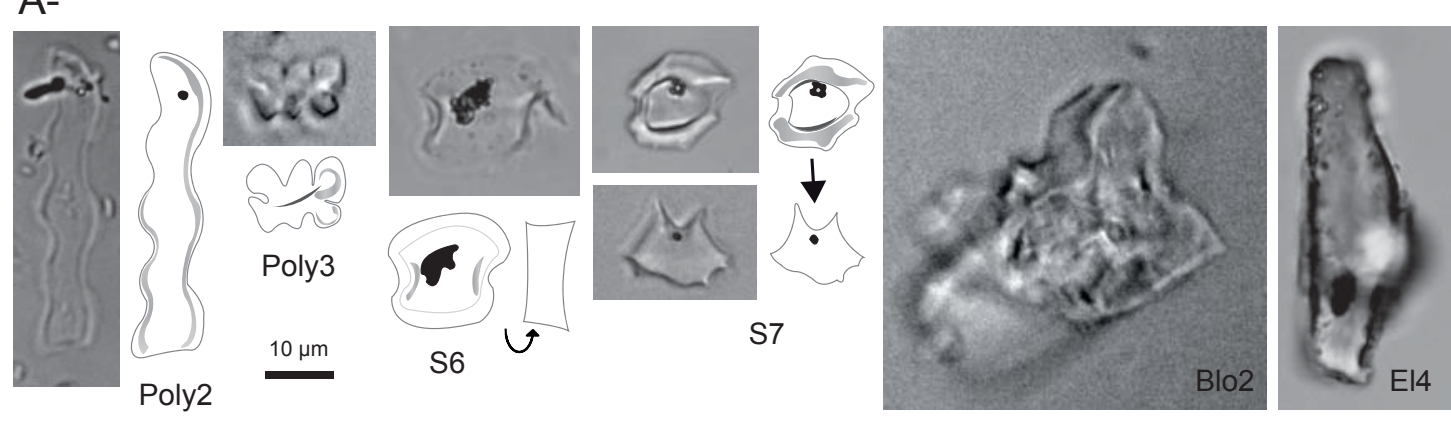

B-

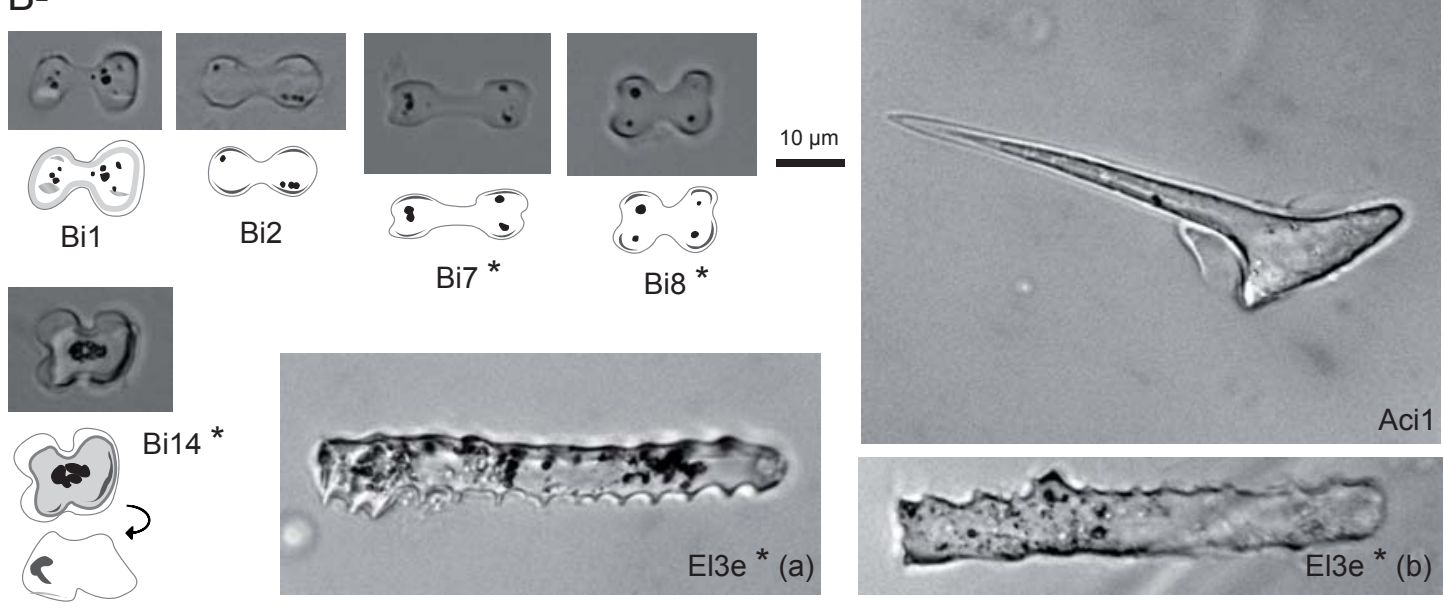

C-

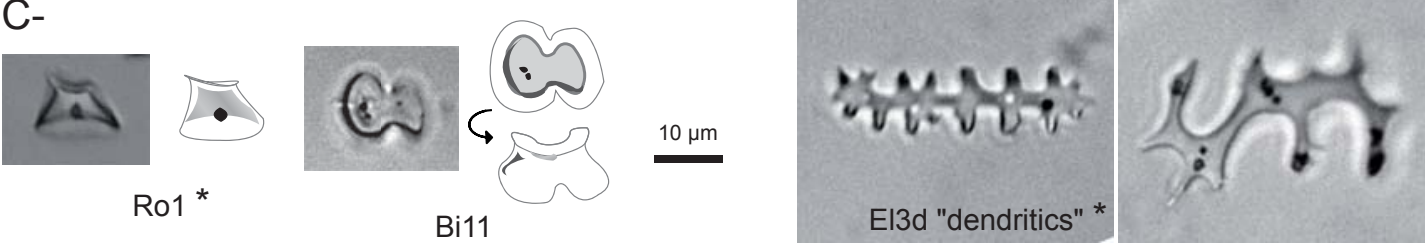

